\title{
UNREGULATED IMMIGRATION LAW CLINICS AND KANT'S COSMOPOLITAN RIGHT: CHALLENGING THE POLITICAL STATUS QUO
}

\section{Omar Madhloom, University of Bristol Law School, UK ${ }^{1}$}

\begin{abstract}
Unregulated law clinics in England and Wales are prohibited from directly offering immigration advice and assistance. This article argues that this restriction should not be a barrier to teaching immigration law. Kant's duty-based ethics and his cosmopolitan right can provide a useful normative framework for challenging the political status quo in relation to the regulation of law clinics and policies affecting migrants. It is argued that introducing normative values into Clinical Legal Education can address the limitations of the conventional 'hired-gun' model and engender students to a more holistic approach to lawyering. In other words, a model which promotes the causes of third parties.
\end{abstract}

Keywords: clinical legal education; cosmopolitanism; hired-gun; immigration law; Kant.

\footnotetext{
${ }^{1}$ Omar Madhloom is a Senior Lecturer and Solicitor at the University of Bristol Law School.
} 


\section{Introduction}

Unregulated law clinics in England and Wales are prohibited from directly offering immigration advice and assistance. This article argues that this restriction on the services clinics can offer should not be a barrier to teaching immigration law. Kant's duty-based ethics and his cosmopolitan right can provide a normative framework for challenging the political status quo in relation to the regulation of law clinics and policies affecting migrants. It is argued that introducing normative values into Clinical Legal Education (CLE) can address the limitations of the conventional 'hired-gun' model and engender students to a more holistic approach. In other words, a model which promotes the causes of third parties.

Normative values are concerned with how things 'ought to be' (Schwieler \& Stefan Ekecrantz, 2011: 60). In the context of CLE, normative values address questions such as 'what is just and fair?', 'do clinic students owe moral duties to non-clients?', and 'do students have a moral duty to engage in law reform?'. Adopting a values-based approach in CLE can contribute to the development of a 'mature moral identity' and fostering an attribute necessary for effective citizenship (Webb, 2010: 9). The term 'values' tends to have a variety of meanings, for present purposes it is regarded as a particular type of belief about what an individual holds valuable, namely human dignity.

Kant's moral philosophy, which is committed to respecting the dignity of all persons, will be applied to CLE to critique the United Kingdom's (UK) current laws and 
policies towards migrants. These policies first entered the political debate in May 2012, when the then Home Secretary, Theresa May, announced the government's aim 'to create, here in Britain, a really hostile environment for illegal immigrants' (Kirkup \& Winnett, 2012). The overarching objective was to make life as difficult as possible for migrants whom the Home Office deemed to be potentially illegal. This policy was not limited to controlling immigration through border control but also included an internal approach. According to Webber (2019: 77), the immigration policies have:

[T] he avowed aim of making life impossible for migrants and refugees who do not have permission to live in the UK, and which remove such migrants from the rights to housing, health, livelihood and a decent standard of living, liberty, freedom of assembly and association, family and private life, physical and moral integrity, freedom from inhuman or degrading treatment, and in the final analysis the right to human dignity and to life.

There are two main reasons for using the UK's 'hostile environment' policies as a casestudy for developing students' analytical skills. Firstly, unregulated law clinics, unless they are partnered with non-government organisations (NGOs) or immigration lawyers, are prohibited from offering immigration advice and assistance. This prohibition can prove to be a barrier to teaching immigration law and theory. Secondly, ethics of immigration (Carens, 2015) can add value to CLE by providing a framework, in the form of normative ethics, for challenging the political status quo. Although there are various forms of cosmopolitanism, this article will draw on Kant's 
theory of cosmopolitanism, the right to hospitality, and his duty-based approach (deontology) to moral decision-making. Deontology is one of several ethical theories ${ }^{2}$ used in CLE. While a CLE curriculum grounded in comparative legal ethics, that includes Kantian philosophy, would better serve the aims of law clinics and CLE, the contribution of Kant's ethics will be the focus of this article.

In the absence of legal obligations, from a student's perspective, towards clients and third parties, Immanuel Kant's theory of ethics, which is the major theory within the deontological tradition (Eberle, 2012: 13), can provide CLE students with a useful framework for identifying their moral duties. Kant's philosophy deals with ethical duties owed by the individual moral agent. He grounds his system upon principles of universality; our moral obligations must be applicable to all people at all times and in similar situations. Kant's critique of the right to hospitality of non-citizens and the duties of the state towards visitors will be applied to the UK's 'hostile environment' policies to develop legal ethics beyond the dominant lawyer-client model found in live-client clinics. This article is based on the premise that there is a need for students to be provided with an ethical framework that promotes respect for the dignity of all individuals, irrespective of their nationality, gender, sexual orientation or any other characteristic.

This article will proceed in seven sections. Section one will argue that the conventional lawyering model, with its value-neutral approach, is inadequate in terms of

\footnotetext{
${ }^{2}$ Other ethical theories include consequentialism, ethics of care, intuitionism, and virtue ethics.
} 
promoting normative values. Public interest lawyering, namely cause lawyering, is a more appropriate pedagogic approach for promoting normative values such as duties towards third parties. Sections two and three identify moral cosmopolitanism as the normative framework for enhancing cause lawyering. Section four will examineKant's deontological ethics and his theory of cosmopolitanism. This section will outline the value of incorporating Kant's concepts of autonomy, respect and dignity to developing the cause lawyering model. Section four will also analyse Kant's cosmopolitan right in order to outline a moral framework for critiquing law and policies affecting migrants. Sections five and six will describe the regulatory framework regarding immigration law and the UK's 'hostile environment' policies. The final section will apply Kant's theory to CLE.

\section{Clinical Legal Education and legal ethics}

CLE is generally understood to mean the provision of pro bono legal services to reallife clients, under the supervision of academic members of staff (Giddings, 2013). While there is no universally accepted definition of CLE, Giddens (2013: 14) puts forward the following explanation:

Clinical legal education involves an intensive small group or solo learning experience in which each student takes responsibility for legal or law-related work for a client (whether real or simulated) in collaboration with a supervisor. Structures enable each student to receive feedback on their contributions and to take the opportunity to learn from their experiences through reflecting on matters including their interactions with 
the client, their colleagues and their supervisor as well as the ethical dimensions of the issues raised and the impact of the law and legal processes.

CLE, as a form of experiential learning, can include a diverse range of teaching methods such as placements, case-studies, and simulations. Consequently, the teaching of law and policies affecting migrants can form part of a CLE curriculum through non-live client models. The value of CLE, as a vehicle for teaching immigration law, is that it not only serves to bridge the gap between theory and practice but can also develop practical skills, 'with the incorporation of the affective domain needed for sensitive and ethical client care' (McAllister, 1997: 3). However, the aim of teaching legal ethics is not to create 'moral whizz-kids' (Hursthouse, 2013: 650), but to provide students with conceptual tools that allow them to address the question: 'how should we respond to this situation?' (Herring , 2017: 4) and more specifically, 'do we owe a moral duty to others?'. With regards to incorporating conceptual tools, such as values, into the curriculum, Webb argues that ' $[\mathrm{i}] \mathrm{f}$ it is to take values seriously, legal education has to become more experiential' (Webb, 2010: 21). This can be achieved through a variety of pedagogies such as CLE, problem-based learning, and simulations. The focus of this article is the role CLE in relation to incorporating normative values. 


\subsection{The 'hired-gun' model}

While a certain amount of guidance for resolving ethical dilemmas can be found in the professional codes of conduct, teaching these rules and duties does little to promote a critical approach to their content (Nicolson, 2018: 88). This article addresses the ethics component of CLE by incorporating a deontological dimension that goes beyond the traditional lawyering model. This aim is achieved through the use of a case-study centred on the UK's immigration law and policies. The analysis of this casestudy requires a normative framework, which the dominant conventional lawyering model lacks. Legal advice and assistance in law clinics incorporates both the conventional lawyering model and its alternative: the public interest lawyering model.

Lawyers in the conventional model are considered to be detached professionals. In other words, neutral partisans who are not associated with the morality, causes, or beliefs of their clients (Chen \& Cummings, 2013: 274). The 'hired-gun' approach is often associated with lawyers in private practice, where the lawyer, in exchange for a fee, defends a client's rights and puts forward the best possible defence. This is carried out without any consideration on the impact on third parties (Herring, 2017: 29). The hired-gun metaphor promotes a value-neutral model where lawyers act as amoral mouthpieces for their clients and zealously pursue their clients' self-interests (Pearce \& Wald, 2016: 601). Defenders of this model view the concept of partisanship as being central to the role of the lawyer (Pepper, 1986: 617-18). According to Fried, a lawyer 
must display 'hyper zeal' in pursuing a client's case, even if this might appear to be unethical (Fried, 1976). The hired-gun approach was recently criticised by the Solicitors Regulation Authority (SRA)3 (2018: 3):

[A]lthough solicitors must advance their clients' cases, they are not 'hired guns' whose only duty is to that client. They also owe duties to the courts, third parties and to the public interest'.

However, the SRA omits to offer any guidance on how these competing interests should be balanced or how a lawyer should determine the meaning of 'public interest'. An alternative model to the 'hired-gun' approach, that has the potential to address the SRA's concerns regarding duties to third parties and to the public interest, is 'public interest lawyering'.

\subsection{Public interest lawyering}

Generally, a public interest lawyer is one who is alert to something or someone beyond their commitment to their client (Chen \& Cummings, 2013: 278). Public interest lawyers embrace a cause which sets them apart from the value-neutral technician who adheres to the conventional model of lawyering. Public interest lawyers who advocate for a cause, such as immigration rights, are driven by a moral commitment (Chen \& Cummings, 2013: 279). Cause lawyering, therefore, aims to 'reconnect law and

\footnotetext{
3 The regulatory body for solicitors in England and Wales.
} 
morality' (Sarat \& Scheingold, 1998: 3) by challenging the central activity of the legal profession, namely the provision of legal services in exchange for payment. This is achieved through amending aspects of the social, political, or economic status quo. A normative framework provides students with a conceptual tool to critique law and policies affecting both clients and non-clients. This framework can facilitate the examination of broader issues such as the impact law and social institutions have on individuals and the extent to which laws and policies hinder or promote persons from realising their life goals. Such analysis goes beyond the narrow confines of the conventional lawyering model. A moral framework that can contribute to the theory of public interest lawyering, in CLE, is Kant's theory of ethics and his cosmopolitan right to hospitality.

\section{Cosmopolitanism}

'Cosmopolitan', derived from the Greek words kosmo and politēs ('citizen of the world'), is a normative ideal used in various disciplines such as education (Papastephanou, 2016), global health justice (Ruger, 2018), moral philosophy (Van Hooft, 2014), and international law (Pierik \& Werner, 2010). Cosmopolitanism is distinguished from globalisation which is associated with the global spread of capitalism and a deregulated market society (Litonjua, 2008: 254). Globalisation has been criticised for promoting neoliberal policies (Knyght et al, 2011) that encourage self-interest (Jordà et al, 2010). Cosmopolitanism, on the other hand, promotes the 


\section{Reviewed Article}

ideal that every individual, regardless of their citizenship status or other affiliation, enjoys equal moral standing (Brock, 2009: 3). Philosophers from Kant to Jacques Derrida associate cosmopolitanism with hospitality to the stranger. Similar to CLE, there is no universally accepted definition of cosmopolitanism. However, Thomas Pogge (1992: 48) outlines three elements shared by cosmopolitan theories:

First, individualism: the ultimate units of concern are human beings, or personsrather than, say, family lines, tribes, ethnic, cultural, or religious communities, nations, or states. The latter may be units of concern only indirectly, in virtue of their individual members or citizens. Second, universality: the status of ultimate unit of concern attaches to every living human being equally - not merely to some sub-set, such as men, aristocrats, Aryans, whites, or Muslims. Third, generality: this special status has global force. Persons are ultimate units of concern for everyone-not only for their compatriots, fellow religionists, or such like.

Pogge's definition is useful to CLE because it draws attention to the moral status of a person as an 'ultimate units of concern'. Moral cosmopolitanism, therefore, views all individuals as members of a single moral community and they owe moral duties to all other individuals, irrespective of their nationality, background, or religion. Cosmopolitanism allows students to adopt the view that there exists a global community which all people, by virtue of their humanity, are members' (Van Hooft, 2014: 6). Cosmopolitanism, therefore, gives rise to moral duties towards individuals outside our immediate community, such as non-citizens. Moral duties can enhance 
CLE in three ways. Firstly, it views 'all humans as worthy of equal moral concern' and advocates 'impartiality and tolerance' (Kleingeld, 1999: 507). Impartiality towards clients may be absent due to the fact that 'unconscious racism and biases often play a role in our everyday decisions' (Lyon, 2012: 758). Thus, incorporating cosmopolitan values into CLE can assist in addressing issues of bias towards clients. This can be achieved through a moral duty-centred approach that promotes self-reflection. Secondly, moral cosmopolitanism provides students with a normative framework for critiquing the content of the professional codes of conduct. Thirdly, it creates a duty towards all persons irrespective of whether they are clients or not. This duty towards clients and third parties can be applied to CLE to engage students in law-reform by providing a 'voice' for those who may not have access to legal representation or who may not be able to access a clinic's services. ${ }^{4}$ Thus, moral cosmopolitanism is closely aligned with the public interest lawyering model. It is necessary to briefly outline Kant's deontological and cosmopolitan theories in order to illustrate their application in CLE.

\footnotetext{
${ }^{4}$ For a discussion on how CLE students can use casework to inform work on law reform, see Curran
} (2007). 


\section{Kant's Ethical Theory}

Kant's duty-based approach to moral reasoning is known as deontology, which is derived from the Greek words for deon (duty) and science (or study) of (logos) (Alexander \& Moore, 2016). Deontology can be contrasted with consequentialism, an umbrella term, that describes ethical theories that frame morality of actions on the types of consequences produced. Examples of consequentialist theories are utilitarianism, egoism, and nationalism (Cohen, 2004: 6). Deontology, on the other hand, places duty, both to one's self and to others, at the heart of morality. For deontologists, an action is deemed to be morally right or wrong not because of the consequences it produces but because it conforms to a specific moral law or principles. In other words, actions are judged not on the cause or effect they produce but on what our duty demands. To apply Kant's theory of ethics to CLE it is necessary to identify the source of this moral duty and what it entails.

By rejecting the consequences of an action as the basis of morality, Kant viewed reason as the foundation of morality. A moral individual is one who is able to deliberate on, and act upon, valid reason. To determine the right moral reason, Kant formulated the Categorical Imperative (CI) as his supreme principle of morality. At the heart of the $\mathrm{CI}$ is the concept of a good will, 'A good will is not good because of what it effects or accomplishes - because of its fitness for attaining some proposed end: it is good through its willingness alone - that is in itself' (Kant, 1948: [4: 394]). A good will relates to an individual's capacity to recognise and to act from a duty to follow the moral law. 


\section{Reviewed Article}

A good will is always good regardless of the consequences it produces, whether intended or not, or even if it fails to produce the intended results (Kant, 1948: 17). In the context of CLE, a good will compliments the professional codes of conduct, which are predominantly consequentialist in nature (Madhloom, 2019), by reminding students to reflect on moral duties such as respecting their own autonomy and that of their clients, being mindful of paternalism towards their clients, and holding the state accountable for morally impermissible actions (Madhloom, 2019).

For an action to be morally good it should not only conform to the moral law but must also be done from a duty towards the moral law (Kant, 1948: [4: 390]). To illustrate this point, Kant gives the example of a grocer who refrains from acting dishonestly towards his customers by overcharging them (Kant, 1948: [4: 397]). Kant argues that there is a difference between a grocer whose actions are in conformity of what is expected of him as a seller, but not necessarily done from a duty to the moral law, and one who conducts his business from the intention to act honestly. It is only in the latter case, acting from duty and the principle of honesty, that the grocer's action can be said to have moral worth. Kant expounds on this point by providing another example, which is of direct relevance to law clinics: that of a person who is not inclined to 'help those in distress' (Kant, 1948: [398]). Their action has moral worth where they, out of duty to the moral law, perform acts which benefits those in distress (Kant, 1948: [4:397]). Kant (1948: [4: 398]) contrasts this example with that of a person who is naturally disposed to assist those in distress: 


\section{Reviewed Article}

I maintain that in such a case an action of this kind, however right and however amiable it may be, has still no genuinely moral worth. It stands on the same footing as other inclinations - for example, the inclination for honour, which if fortunate enough to hit on something beneficial and right and consequently honourable, deserves praise and encouragement, but not esteem; for its maxim lacks moral content, namely the performance of such actions, not from inclination, but from duty. ${ }^{5}$

A person's moral worth, whether a client or not, is not dependent on inclinations or feelings. What drives a person's actions is recognition of duty, rather than the consequences of an action. It is this reasoning which led Kant to reject utilitarianism. The moral worth of an action is not judged by the consequences it produces or intended effect but by the fact that it was motivated by duty. The concept of duty helps shift the focus from the amoral 'hired-gun' approach to a more public interest lawyering model which promotes the examination of our duties towards ourselves, our clients, and society.

Kant's CI raises the question 'why are only acts that are motivated by duty possess moral worth?'. This 'motivational rigorism' (Timmermann, 2009: 58) is a result of Kant's interest in developing an account of ethics that is concerned with a person's character. Clinic students who, out of duty for the moral law, show care for third parties, whom they do not owe any legal duties towards, can be said to be have moral worth. Incorporating the concept of a moral duty towards clients and third parties can

\footnotetext{
${ }^{5}$ Emphasis in the original. This applies to all subsequent quotes.
} 
promote a critique of law and policies affecting those individuals and groups such as migrants and non-citizens. To determine our duties to the moral law, it is necessary to examine Kant's supreme principle of morality.

4. Kant's supreme principle of morality: The Categorical Imperative

Kant formulated the CI to distinguish between right and wrong actions. The CI is an unconditional command that is binding irrespective of the outcome or whether it serves a benefit, either directly or indirectly, to us personally. Although Kant insists that there only one $\mathrm{CI}$, he provides various formulations of it each with a different emphasis:

1. The Formula of Universal Law: 'Act only on that maxim through which you can at the same time will that it should become universal law' (Kant, 1948: [4: 421]);

2. The Formula of Humanity: 'Act in such a way that you always treat humanity, whether in your own person or in the person of another, never simply as a means, but always at the same time as an end' (Kant, 1948: [4: 429]);

3. The Formula of Autonomy: 'the Idea ${ }^{6}$ of the will of every rational being as a will which makes universal law' (Kant, 1948: [4: 431); and

\footnotetext{
${ }^{6}$ 'Idea' with a capital 'I' refers to Kant's technical term. An Idea is a rational concept which arises out of our knowledge of the empirical world, yet seem to point to a transcendent realm. Once such Idea is 'the greatest possible human freedom according to laws, by which freedom of every individual is consistent with the freedom of every other' (Kant, 2015: [A316/B372]).
} 
4. The Formula of Kingdom of Ends: 'Act on the maxims of a member who makes universal laws for a merely possible kingdom of ends' (Kant, 1948: [4: 439]).

The various formulations of the CI will be briefly discussed to illustrate their application in critiquing laws and policies affecting migrants.

\subsection{The Formula of Universal Law}

The CI, according to Kant, is the principle for achieving consistency and universalisation of our maxims. A maxim is a 'subjective principle of action...on which the subject acts' (Kant, 1948: n 51). The CI can provide students with a conceptual tool to determine whether their maxim, which underpins their actions, can be applied universally, that is, to everyone including themselves. Maxims are useful in that they identify contradictions (Kant, 1948: [4: 424]):

Some actions are so constituted that there cannot even be conceived as a universal law of nature without contradiction let alone willed as what ought to become one. In the case of others we do not find this inner impossibility, but it is impossible to will that their maxim should be raised to the universality of law of nature, because such a will would contradict itself.

There are two types of maxims: those that are contradictory when they are applied, and those that cannot be willed to be universally applied. Kant provides the example of willing a world in which we do not help 'others who have to struggle with great 
hardship' (1948: [4: 423]). There is clearly no contradiction in conceiving of such a maxim when applied universally. The maxim is not self-defeating in the same manner that it is possible to envisage such a society. However, willing a principle in which we do not help those suffering hardships, such as clients who are unable to access legal assistance, would result in a conflict with itself; there may come a time when we may need help from others, but none would be forthcoming as we could have willed that we do not receive any assistance. Thus, the Formula of Universal Law allows students to reflect on actions beyond the conventional value-neutral lawyer-client model. It promotes reflection on laws and policies that disadvantage certain groups such as migrants.

\subsection{The Formula of Humanity}

In relation to the second formula, 'humanity' includes the capacity to set ends for oneself (Korsgaard, 1996: 110). This capacity is a feature of a person's freedom, understood as the ability to self-govern. In other words, the freedom to engage in selfdirected rational behaviour and to set ends for ourselves (Johnson \& Cureton, 2019). To exercise freedom to set ends for oneself (positive freedom) clients must be free from interference such as coercion and deception (negative freedom). Christine Korsgaard writes (1996: 140-141):

According to the Formula of Humanity, coercion and deception are the most fundamental forms of wrongdoing to others - the roots of all evil. Coercion and 
deception violate the conditions of possible assent, and all actions which depend for their nature and efficacy on their coercive or deceptive character are ones that others cannot assent to...Physical coercion treats someone's person as a tool, lying treats someone's reason as a tool. That is why Kant finds it so horrifying; it is a direct violation of autonomy.

For Kant (1948: [4: 447]), a free or autonomous individual is one whose motives and actions are in accordance with the moral law. However, it is permissible to use coercion in certain circumstances if the aim is to promote positive freedom (Kant, 1996: $[6: 231]):$

[I]f a certain use of freedom is itself a hinderance to freedom in accordance with universal laws...coercion that is opposed to this (as a hindering of a hinderance to freedom) is consistent with freedom in accordance with universal laws...it is right.

The state can limit our freedom provided the purpose is to promote freedom generally, such as criminalising theft and murder. Kant articulates the linkage between rights, freedoms, and equality by stating that the 'civil state' (Kant, 2006: [8:290]) ought to be based on the following principles (Kant, 2006: [8:290]):

1. The freedom of every member of society as a human being.

2. The equality of each member with every other as a subject.

3. The independence of every member of the commonwealth as a citizen. 
With regards to freedom, 'the member of the commonwealth, is entitled to this right... as a human being to the extent that the latter is a being capable of rights in general' (Kant, 2006: [8:290]). A 'state' is defined as 'a union of a multitude of human beings under laws of right' (Kant, 1996: [6: 230]). Kant uses 'state' and 'peoples' (Kant, 1996: [6: 312]) synonymously suggests that states and their peoples have the same duties towards migrants that they owe towards their own. Thus, it can be argued that unregulated law clinics owe a duty to third parties. He defines 'right' as 'the sum of the conditions under which the choice of one can be united with the choice of another in accordance with a universal law of freedom' (1996: [6: 313]). This 'universal law of freedom' or 'the universal principle of right' maintains (Kant, 1996: [6: 230]):

Any action is right if it can coexist with everyone's freedom in accordance with a universal law. or if on its maxim the freedom of choice of each can coexist with everyone's freedom in accordance with a universal law'.

Individuals are, therefore, free to act in whatever manner they see fit, provided their actions do not interfere with the freedom of others. A client's ability to set 'ends' for themselves gives rise to the notion of respect in relation to the 'rational choices, the plans, and intentions we and others may form' (Nelson, 2008: 104). Stephen Darwall distinguishes between two types of respect: 'appraisal respect' and 'recognition respect' (Darwall, 1977). Appraisal respect involves a positive appraisal of a person either as a person or in relation to their engagement of a particular enterprise. This type of respect is determined following an evaluation of other individuals to 


\section{Reviewed Article}

determine whether the person, when judged by objective standards, has special merit and deserves our respect (Darwall, 1977: 39). The latter refers to the attitude of regard for others which is due to their being persons, and as such, worthy of being respected by virtue of the fact that they are persons deliberating on their actions. Recognition of respect is 'not how something is to be evaluated or appraised, but how our relations to it are to be regulated or governed' (Darwall, 2006: 123). Unlike appraisal respect, recognition respect requires that we demonstrate respect for others not because of our appraisal of them but because we are morally obliged to do so (Allan \& Davidson, 2013: 347). In other words, recognition respect does not require fulfilling a standard of evaluation appropriate to the individuals. Darwall's recognition respect captures Kant's notion of respect which must be afforded to every individual (Kant, 1996: [6:464]):

I cannot deny all respect to even a vicious man as a human being; I cannot withdraw at least the respect that belongs to him in his quality as a human being, though though by his deeds he makes himself unworthy of it.

We ought to have recognition respect even for people whom we do not have appraisal respect for. This creates a moral justification for defending the guilty ${ }^{7}$ on the ground that respect is not a matter of degree based on the recipient, for example a client, of our respect having met some standard of assessment (Johnson \& Cureton, 2019). This raises the question as to why we are obliged to morally respect every person no matter

\footnotetext{
${ }^{7}$ In relation to the ethics of criminal defence, see (Mitchell, 1980); (Markovits, 2003); (Seleme, 2013).
} 
their character or actions. According to Kant, respect towards others is necessary due to their dignity (Kant, 1948: [4: 435]). Sandel (1996: 82) equates dignity with a person's capacity as an autonomous agent to choose their ends for themselves. Following Sandel's interpretation, autonomy presupposes an individual's ability to make choices free from external constraints. In the context of CLE, external constraints on personal autonomy include undue influence from a student advisor as well as laws that prevent people from realising their life goals. The concept of a person's dignity is further explored in Kant's Formula of Autonomy.

\subsection{The Formula of Autonomy}

Autonomy, Kant (1948: 4: 436) writes, 'is the ground of the dignity of human nature and of every rational nature'. As a human moral creature, what Kant calls 'homo noumenon' (1996: 6: 434), a person exists in the moral realm of dignity. It is this dignity, inherent in every person, that demands respect because 'every man has a legitimate claim to respect from his fellow men and is in turn bound to respect every other' (1996: 6: 462). Kant (1948: [4: 435]) differentiates things which can have a 'price' and can be exchanged for something else, and things with a 'dignity' which are 'exalted above all price' and have no equivalent. Individuals possess unconditional value compared to other things, such as material goods, which can be valued by persons. Clients and third parties are, therefore, not to be valued simply as a means to the ends of others but as ends in themselves by virtue of their dignity. An example of 
using a client as means is where a student volunteers in a clinic purely out of selfinterest as opposed to altruistic reasons. For Kant (2015: [5:88]), a person's value as a rational being is linked to their autonomy:

A human being alone, with him every rational creature, is an end in itself: by virtue of the autonomy of his freedom he is the subject of the moral law...such a being...is to be used never merely as a means but as at the same time an end.

Dignity, as a universal concept, is possessed by every individual due to their autonomy and is grounded in the requirement to treat others, including their own person, 'as ends in themselves' (Bognetti, 2005: 89-90). However, historically, individuals outside one's national borders were not considered to have moral standing (Chadwick \& O'Connor, 2015: 26). Individuals with moral standing are those who are considered to be moral agents. For Kant (1948: [4: 435]), a moral agent is one who possesses dignity. Moral agency is essential to being a rational agent (Bowie, 1999: 45). In relation to the concept of rationality, Kant writes (1948: [4: 429]):

Rational nature exists as an end in itself. This is the way in which a man necessarily conceives his own existence: it is therefore so far a subjective principle of human actions. But it is also the way in which every other rational being conceives his existence on the same rational ground which is valid also for me; hence it is at the same time an objective principle, from which as a supreme practical ground, it must be possible to derive all laws for the will. 
This highlights Kant's assertion for the necessity of respecting all rational individuals because rationality is a product of an individual's freedom and enables them to act as moral agents (Kant, 1948: [4: 447]). Freedom permits individuals to act on laws they formulate themselves rather than being subjected to causal laws. Therefore, moral agency is what gives individuals dignity (Bowie, 1999: 45). The concepts of freedom and dignity can be useful analytical tools for critiquing the principle that lawyers must act with independence (SRA, Principle 3) and acting in their clients' best interests (SRA, Principle 7). Taking into consideration a person's freedom and dignity allows students to be mindful of a client's dignity by virtue of them being autonomous persons. This dignity-centric approach to client care may prevent students from being paternalistic when advising their clients. A further advantage of this approach is that it allows students to reflect on the impact of law and policies, which restrict freedom, on persons who are outside their immediate community. This is achieved by incorporating into CLE the concept of a moral community that transcends geographical boundaries, namely Kant's 'kingdom of ends'.

\subsection{Formula of Kingdom of Ends}

Kant's third formula requires that actions be considered as if their maxims provide a law for a hypothetical 'kingdom' (1948: [4: 433]). A 'kingdom' is 'a systematic union of different rational beings under common laws' (1948: [4: 433]). A kingdom of ends is an ideal community of rational beings living in harmony with one another. Unlike 
'humanity', which every person possesses, a kingdom of ends is an ideal which every person should strive to achieve (Hildebrand, 2017: 23). This formula conceptualises Kant's ideal community where the authority that legislates moral laws and norms are binding on everyone. These norms are derived from rational standards accessible to all the community's members and accord with their dignity (Hildebrand, 2017: 23). The Formula of the Kingdom of Ends acts as a domain for the normative framework necessary for a cosmopolitan community. In his essay ‘Toward Perpetual Peace' (TPP), Kant argues that, ' $[t]$ he growing prevalence of a (narrower or wider) community among the peoples of the earth has now reached a point at which the violation of right at any one place on the earth is felt in all places' (Kant, 2006: [8:360]).It would seem that Kant anticipated the current climate change (European Commission, 2020a) and refugee crises (European Commission, 2020b) whereby catastrophes in one part of the world may have consequences on other nations (Mader\& Schoen, 2019). This can create a realisation in students that they 'are not citizens justof specific nation-states but are also citizens of the world' (Van Hooft, 2009: 4).

\subsubsection{Kant's cosmopolitan right}

In TPP, Kant (2006: [8: 358]) equates the idea of a 'Cosmopolitan Right' to 'hospitality' which he defines as 'the right of a stranger not to be treated in a hostile manner by another upon his arrival on the other's territory'. Kant (2006: [8: 357]) limits his cosmopolitan right to 'Universal Hospitality'. The use of the word 'universal' implies 
that this cosmopolitan right is a type of CI valid for everyone (Saji, 2009: 126). Thus, any person can exercise the right to arrive on any land. However, Kant's cosmopolitanism, which is a right as opposed to philanthropy (Kant, 2006: [8: 358]), is not an absolute right. A stranger can be turned away provided this can be achieved without their death (Untergang) and the stranger must not be treated with hostility, 'so long as he behaves in a peaceable manner in the place he happens to be' (Kant, 2006: [8: 358]). Under this right, non-citizens can claim the 'right of resort', which everyone possesses 'by virtue of the right of common possession of the surface of earth' (Kant, 2006: [8: 358]). The right of resort is merely an entitlement to present oneself in the lands of others. Kant's cosmopolitan right is not 'a right to make a settlement on the land of another nation (ius incolatus)' (1996: [6: 353]). A non-citizen's right to 'make a settlement' can only be secured through a special contract (Kant, 1996: [6: 353]). Kant elaborates on this conditional requirement by stating that it requires 'a special, charitable contract stipulating that he be made a member of the household for a certain period of time' (Kant, 2006: [8: 358]).

Kant's hospitality model, which is limited to a right to visit (Besuchsrecht) rather than a right to residence (Gastrecht), has been described as being 'inappropriate' (Cavallar, 2002: 323) and 'empty' (Benhabib, 2004: 36). Derrida criticises Kant for providing a restricted right to hospitality that gives rise to a precedent for the special conditions imposed on refugees and asylum seekers (Derrida, 2001). This criticism appears, at first glance, justified when we consider that in relation to a stranger's right to visit, the 
state has the authority to refuse entry with respect to non-citizens, and thereby overriding a stranger's right to hospitality. However, Derrida's (2001) reading of Kant, namely the exclusion of asylum seekers in Europe, is unjustified because Kant's laws of hospitality explicitly hold that visitors should not be turned away if it results in their 'death' (Kant, 2006: [8: 358]). Kant's narrow conception of the right to hospitality can be disregarded in relation to CLE because this right which 'pertains...only to conditions of the possibility of attempting to interaction with the old inhabitants' (Kant 2006: [8 358]), was primarily aimed at restricting European colonisation (Kant, 2006: [8: 358]; see also Brown, 2-14: 684):

If one compares with this the inhospitable behaviour [sic] of the civilized states in our part of the world, especially the commercial ones, the injustice that the latter show when visiting foreign lands and peoples (which to them is one and the same as conquering those lands and peoples) takes on terrifying proportions.

Kant (2006: [8: 358]) restricts the right of hospitality to visiting other countries. For European states this meant colonisation and 'oppression of the native inhabitants'. Kant's cosmopolitanism was, therefore, mainly concerned with restraining colonial rule and aggression (Kleingeld, 1998: 76). He (Kant, 1996: [6: 353]) attempts to introduce a further limit on European colonialism by excluding from the right to visit 'a right to make a settlement on the land of another nation (ius incolatus)'. Although Kant did not explicitly mention the rights of refugees and economic migrants, the plight of 
refugees in eighteenth-century Europe ${ }^{8}$ is unlikely to have escaped his attention. In an early draft for TPP Kant (cited in Kleingeld, 1998: 78) argues that 'a ship seeking a port of refuge in a storm, or a stranded group of sailors cannot be chased away from the beach...where he saved himself and sent back into imminent danger...instead, he must be able to stay there until there is a favourable opportunity to leave'. Here, Kant not only anticipates the rights of refugees but also the principle of non-refoulment established in the twentieth century (Kleingeld, 1998: 77; on the rights of refugees, see Goodwin-Gill \& McAdam, 2007). Under customary international law and the Convention Relating to the Status of Refugees (1951 and 1967) (the Refugee Conventions), states are prohibited from removing individuals from their jurisdiction when there are substantial grounds for believing that an individual would be at risk of harm upon return, including persecution, torture or other serious human rights violations based on their 'race, religion, nationality, membership of a particular social group or political opinion' (Article 33 of the Convention Relating to the Status of Refugees 1951). Using the Refugee Convention as a frame of reference, Kant's theory of cosmopolitanism 'has some room for limits on the range of legitimate reasons for rejection' (Kleingeld, 1998: 77). Thus, a state's laws, which prevent individuals from exercising their right to hospitality, are discriminatory and contrary to the CI.

As stated previously, a stranger should only be turned away if it can be carried out without causing their death (Kant, 2006: [8:358]). Can the state refuse entry to an

\footnotetext{
${ }^{8}$ For an account of refugees in eighteenth-century Prussia see Hans Fenske, 'International Migration: Germany in the Eighteenth Century' (1980) 13(4) Central European History 332.
} 
asylum seeker if this would not result in death on return to their country of origin? Kant's right to hospitality appears to allow such an action on the part of the state. However, Pauline Kleingeld (1998: 76) argues that Kant's term ‘Untergang', which she interprets as 'destruction', ${ }^{9}$ can include 'mental destruction or incapacitating physical harm'. It is, therefore, possible to widen Kant's cosmopolitanism to include migrants who would suffer or are at risk of suffering 'destruction', as interpreted by Kleingeld, if they were to be deported. This interpretation of Kant's cosmopolitanism does not imply that states lose their powers to exclude non-citizens. On the contrary, Kant (2006, [8: 359]) himself supported China and Japan in their attempts to limit interaction with European traders. Kant's cosmopolitanism supports state sovereignty in four ways. Firstly, it permits states to limit interaction with non-citizens. Secondly, migrants can be turned away provided this can be achieved without causing their destruction (broadly defined). Thirdly, non-citizens do not have an a priori right to settle, they only have a right to visit. Fourthly, the right to hospitality can be revoked if a migrant fails to behave in a peaceable manner. Kant does not explain what constitutes 'behaves peacefully', but presumably what he had in mind was a visitor adhering to the norms and laws of the host state. Conversely, he limits state sovereignty by requiring a state to fulfil four conditions (Saji, 2009: 127). Firstly, every non-citizen is to be treated equally and without hostility provided they behave peacefully. Secondly, as long as a non-citizen behaves peaceably, they should not be

\footnotetext{
${ }^{9}$ In some translations this term is interpreted as 'death'.
} 
forced to conform to the people of the state simply because they have entered the state's territory (Saji, 2009: 128). Thirdly, but unlike the first two conditions which are unconditional, a stranger can enter into a specific contract to 'make settlement in the land of another nation' (Kant, 1996: [6: 353]). Finally, admission is obligatory if refusal of entry will lead to the individual's destruction.

Kant's cosmopolitanism is a useful analytical tool for teaching immigration law in CLE because it affirms an individual's humanity through respect for their autonomy and the requirement to afford them hospitality, albeit on the condition that an individual behaves peacefully. It provides a framework for recognising that individuals have a moral right to travel within a global community and not to be treated with hostility. Kant's Kingdom of Ends and his theory of cosmopolitanism can develop public interest lawyering by introducing a deontological approach to cause lawyering. Kant's CI can, therefore, provide the foundation of our moral duties towards society and acts as a framework for critiquing the law. To demonstrate the application of Kant's ethics to CLE, it is necessary to provide a brief overview of the current regulatory framework regarding the provision of immigration advice and assistance.

5. Law clinics and regulation of immigration advice and assistance In England and Wales, the Office of the Immigration Services Commissioner (OISC) regulates the provision of immigration advice and services in the UK. 'Immigration advice' and 'immigration services' are defined in s. 82(1) of the Immigration and 
Asylum Act 1999 (IAA 1999). Section 84(2) of the IAA 1999 allows persons to provide immigration advice and services provided they are authorised to practise by a designated qualifying regulator. The SRA, which derives its regulatory authority from the Law Society, is a designated qualifying regulator. Anyone in England and Wales is permitted to offer legal advice, provided they do not 'hold' themselves out to be a qualified person. However, only a qualified person may provide immigration advice or services. A person who offers immigration advice or immigration services in contravention of s. 84 of the IAA 1999 is guilty of a criminal offence. The IAA 1999, therefore, prohibits unregulated university law clinics from offering immigration advice and services. The OISC's Position Statement (2018) justifies this framework of regulation on the grounds that 'those seeking immigration advice and/or services in the UK should receive them from persons who are fit and competent'. However, this argument can apply to law clinic clients generally in that unregulated clinics are permitted to offer legal support to vulnerable clients without the need for regulation. Section 84 of the IAA 1999 could, therefore, be amended to allow unregulated clinics to provide immigration advice and assistance. To apply a cosmopolitan approach to clients and third parties, in CLE, it is necessary to examine the relevant law affecting certain migrants. 
6. The United Kingdom's 'hostile environment'

The UK's policies on immigration control were translated into legislation by the Immigration Acts of 2014 (IA 2014) $)^{10}$ and 2016 (IA 2016).${ }^{11}$ The government sought, through the IA 2014, to make it 'harder for illegal immigrants to rent accommodation' (United Kingdom. Parliament, 2014). Sections 22 - 28, inclusive, of the IA 2014 create an obligation on landlords of private rental accommodation to conduct checks for the purpose of establishing that tenants have the 'right to rent'12 in the UK. Landlords who rent to illegal migrants without conducting these checks will be liable for a civil penalty. In $R$ (on the application of Joint Council for the Welfare of Immigrants) $v$ Secretary of State for the Home Department [2020] EWCA Civ 542, the Court of Appeal held the scheme to be compatible with European Convention on Human Rights (ECHR) Article $144^{13}$ in conjunction with Article $8 .{ }^{14}$ The Court upheld the legality of the right to rent scheme that requires landlords to check the immigration status of tenants. Despite finding that the scheme did, to an extent, increase the risk of discrimination, Hickinbottom LJ ( $R$ (on the application of Joint Council for the Welfare of Immigrants) $v$

\footnotetext{
10 Received Royal Assent on 14 May 2014.

${ }^{11}$ Received Royal Assent on 12 May 2016.

12 Right to rent means simply that the occupier has a right to rent a property in the UK.

13 The enjoyment of the rights and freedoms set forth in this Convention shall be secured without discrimination on any ground such as sex, race, colour, language, religion, political or other opinion, national or social origin, association with a national minority, property, birth or other status.

14 1. Everyone has the right to respect for his private and family life, his home and his correspondence.

2. There shall be no interference by a public authority with the exercise of this right except such as is in accordance with the law and is necessary in a democratic society in the interests of national security, public safety or the economic wellbeing of the country, for the prevention of disorder or crime, for the protection of health or morals, or for the protection of the rights and freedoms of others.
} 
Secretary of State for the Home Department [2020] EWCA Civ 542, para. 75), delivering the leading judgment, stated:

I am satisfied that, as a result of the Scheme, some landlords do discriminate against potential tenants who do not have British passports, and particularly those who have neither such passports nor ethnically-British attributes such as name. By "as a result of the Scheme", I mean that, but for the Scheme, the level of discrimination would be less. Almost all of the evidence - notably the evidence from mystery shopping exercises and surveys - points clearly in that direction.

The Court concluded that those who do have a right to rent, but not a British passport, were subject to discrimination based on their nationality. However, the Court highlighted that this discrimination is not a rational or logical outcome of the scheme. According to the Court ( $R$ (on the application of Joint Council for the Welfare of Immigrants) v Secretary of State for the Home Department [2020] EWCA Civ 542, para. 151), the scheme is a 'proportionate means of achieving its legitimate objective' and, therefore, justified.

Section 38 of the IA 2014 also requires temporary migrants to make contributions to the National Health Service (NHS). ${ }^{15}$ Uthayakumar-Cumarasamy (2020: 133) criticises this 'weaponization' of the UK health service:

'[H]ostile environment' policies are designed to be most detrimental to some of society's most marginalized and vulnerable, such as undocumented migrants and

\footnotetext{
${ }^{15}$ Umbrella term for the publicly-funded healthcare systems of the UK.
} 
unidentified victims of trafficking, creating an underclass whilst more privileged groups continue to benefit from access to healthcare.

The IA 2016 extends the scope of the 'hostile environment' policy by introducing new sanctions on illegal workers, preventing certain migrants from accessing housing, and new measures to deport illegal immigrants.

In April 2013, the Legal Aid, Sentencing and Punishment of Offenders Act 2012 (LASPO) came into effect. LASPO, which was introduced, inter alia, in response to increasing pressure on the legal aid budget, resulted in funding cuts to legal aid and narrowed the scope and financial eligibility criteria. Three areas of law that have suffered extensive scope cuts as a result of LASPO are housing, welfare benefits and immigration. Consequently, many individuals who would previously have been eligible for legal aid have been unable to gain legal assistance to pursue their cases in court or at a tribunal (Law Works, 2018).

Immigration lawyers have also been the target of the government's immigration policies. The Civil Legal Aid (Remuneration) (Amendment) (Coronavirus) Regulations 2020 (Coronavirus Regulations 2020), ${ }^{16}$ which amend the fee regime for legal aid providers, have been criticised for not adequately reflecting the work required by immigration lawyers. According to the Immigration Law Practitioners' Association (ILPA) the new fee regime 'will inevitably deter people from taking on

\footnotetext{
${ }^{16}$ Came into force on 8 June 2020.
} 
the more complex cases, which require the most work' (ILPA, 2020). The next section will apply Kant's philosophy to CLE.

\section{Applying Kantian ethics to CLE}

Kant's theory of ethics is a useful analytical tool for enhancing student reflection and analysis of the law for three reasons. Firstly, it is committed, through the CI, to the equal moral worth of rational individuals, regardless of their nationality, religion, or any other characteristic. In other words, individuals are considered 'equal' irrespective of their citizenship and background (Barry, 1998: 145). This ethical framework demands that we show concern not just for our fellow citizens but for all human beings, especially those who are affected by poverty, war, climate change or injustice. Secondly, we have a moral duty to promote a person's autonomy,including our own. Thirdly, students are encouraged to reflect on whether maxims leading to coercive laws and policies that restrict the freedom and autonomy of certainmigrants, can be willed to be a universal law.

The University of Bristol's CLE < http://www.bristol.ac.uk/law/law-clinic/ > programme introduces Kant's theory of ethics to students through lectures thatoutline the various formulations of the CI. This ensures students gain an awareness of a deontological approach to legal ethics. The emphasis in the lectures is on the dignity and autonomy of all persons, as opposed to focusing solely on clients. Prior to the workshops, students are provided with pre-reading material on cosmopolitanism, 
Kant's ethics, the regulation of legal services, and the relevant laws and policies affecting migrants. Seminar questions are designed to promote analysis and critique of the law and policies through a cosmopolitan lens. The starting point of critique of the UK's policies is whether migrants have a moral right to hospitality. As stated above, non-citizens have a moral right to visit and must not be turned away if this would result in their destruction. Students are then asked to examine the impact the IA 2014 and 2016 have on non-citizens' autonomy. Policies that prevent a person from accessing employment, housing, legal advice, and medical care not only prevent her from realising her life goals but also cannot be morally justified according to Kant's theory of cosmopolitanism which creates a right to hospitality.

A deontological approach to legal practice can also draw attention to the fact that certain migrants are prevented from accessing legal advice because of the restrictions placed on unregulated law clinics and the fee structure introduced by the Coronavirus Regulations 2020. Reflecting on the impact of the law on third parties has the potential to enhance students' reflective practice and critical analysis. With regards to developing public interest lawyering in CLE, Kantian's theory of ethics can direct the student's attention to the fact that they, as moral agents, have a role to play in law and policy reformin relation to unjust practices. Kant (2006: [8: 304]) argues that citizens have the right to inform their governments of any injustices and petitionfor redress and reform. This right ensures that we owe a moral duty not just to clientsbut also to those who do not fall within the scope of a clinic's work such as asylum 
seekers. This creates a moral right, as far as clinic are concerned, to engage in policy reform. A clinic can inform the state of any injustices and petition for reform through partnering with NGOs and immigration law firms.

The University of Bristol's Law Clinic fulfils this moral duty by partnering with Bail for Immigration Detainees (BID) $<$ https://www.biduk.org/pages/2-about-us $>$, an independent charity that exists to challenge immigration detention in the UK. This partnership allows students to apply cosmopolitan theory to assist BID with policy reform and research reports. This facilitates an understanding and appreciation of the some of the issues facing migrants. Analysing the issues facing migrants provides students with the opportunity to develop their nascent emotional intelligence (Douglas, 2015) through exposure and analysis of the laws and policies affecting migrants. Thus, even though immigration law is regulated, clinic students can still take an active role in promoting the causes of third parties.

\section{Conclusion}

This article has demonstrated that unregulated law clinics can engage, albeit indirectly, with immigration clients through a cosmopolitan approach grounded in a duty towards all individuals. Kant's cosmopolitanism theory adds value to CLE by firstly recognising the dignity of both clients and third parties. Secondly, there has been a gradual shift in recent years towards a more social justice-oriented approach in CLE (Nicolson, 2016; McKeown \& Ashford, 2018). Kant's CI can contribute to this 
approach by introducing a normative framework for students to pursue social and political justice which focuses on the autonomy and freedom of all rational persons. Thirdly, Kant's cosmopolitan right, which refers to 'conditions of universal hospitality' (Kant, 2006: [8: 357]), recognises that individuals ought to be free to move to different parts of the world and, thus, providing a norm for assessing situations which result in oppression, such as barriers to trade and interaction (Nascimento, 2016: 108). Fourthly, cosmopolitanism promotes the ideal that individuals ought to be free from national, cultural, and political biases (Waldron, 1999; Caney, 2005; Nussbaum, 2010). Law students and individuals generally are susceptible to confirmation bias, ego-centric and self-serving biases (Adler, 2005; Eigen \& Listokin, 2012; Stark \& Milyavsky). This issue of bias in CLE is of particular relevance given that the SRA states that a solicitor is under an obligation to 'act with independence' (SRA, Principle 3). A student's heuristic bias may affect their ability to maintain impartiality and independence towards their client. CLE programmes have been criticised for minimising the importance decision-making skills, namely 'study of the cognitive strategies needed to properly identify and prioritize goals, to process information free of psychological biases that undermine objectivity, and to creatively generate potential solutions to a problem' (Rand, 2003: 733). Kant's cosmopolitanism allows students to address discrimination, whether their own or resulting from a social institution such as the Home Office, towards clients and third parties who happen to be members of a different nationality, ethnicity, or any other form of identity designed to label individuals as members of discreet groups. Fifthly, cosmopolitanism fosters a 
moral obligation 'to the worldwide community of human beings' (Nussbaum, 2010: 155). This allows students to reflect on duties beyond those prescribed by the professional codes of conduct: duties towards their clients, the court, and, in limited circumstances, towards third parties. A cosmopolitan moral obligation, on the other hand, provides students with an opportunity to reflect on issues beyond their immediate community, such as climate change, refugee crisis, and the Covid-19 pandemic. Limiting the scope of universalizability to ones' own community or country risks 'educating a nation of moral hypocrites, who talk the language of universalizability but whose universe has a self-servingly narrow scope' (Nussbaum, 2010; 160). Moreover, the Formula of Universal Law creates a moral duty, incumbent on individuals not to act selfishly by disregarding the plight of others. This formula, therefore, promotes public interest lawyering.

Finally, cosmopolitanism can add value to the legal profession beyond CLE. It can develop legal practice by engaging lawyers in three levels of analysis. The first level focuses on an individual's (client, lawyer, or third parties) autonomy and dignity. Second, the organisational level promotes reflection on corporate social responsibility, and the moral permissibility of in-house policies that benefit only a small number of stakeholders in an organisation. The third level concerns duties towards the moral community, be it a law firm, immediate community, or other jurisdiction. 
References

Adler, R. S. (2005). Flawed thinking: addressing decision biases in negotiation. Ohio State Journal on Dispute Resolution, 20(3), 683-774.

Alexander, L., \& Michael, M. (2016). Deontological Ethics. In E. N. Zalta (Ed.), The Stanford Encyclopedia

of Philosophy.

https://plato.stanford.edu/archives/win2016/entries/ethics-deontological/

Allan, A., \& Davidson, G. R. (2013). Respect for the dignity of people: what does this principle mean in practice? Australian Psychologist, 48(5), 345-352.

Ashford, C., \& McKeown, P. (Eds.). (2018). Social justice and legal education. Cambridge Scholars Publishing.

Barry, B. (1998). International society from a cosmopolitan perspective. In D. Mapel \& T. Nardin (Eds.), International Society: Diverse Ethical Perspectives (pp. 144-163). Princeton University Press.

Benhabib, S. (2004). The Rights of Others: Aliens, Residents and Citizens. Cambridge University Press.

Benhabib, S. (2006). 'The philosophical foundations of cosmopolitan norms'. In R. Post (Ed.), Another cosmopolitanism (pp. 13-44). Oxford University Press.

Bognetti, G. (2005). The concept of human dignity in European and US constitutionalism. In G. Nolte (Ed.). European and US constitutionalism (pp. 85-107). Cambridge University Press. 
Bowie, N. E. (2017). Business Ethics: A Kantian Perspective (2nd ed.). Cambridge University Press.

Brock, G. (2009). Global justice: a cosmopolitan account. Oxford University Press.

Brown, G. W. (2014). The European Union and Kant's idea of cosmopolitan right: Why the EU is not cosmopolitan. European Journal of International Relations, 20(3), 671-693.

Carens, J. (2013). The ethics of immigration. Oxford University Press.

Cavallar, G. (2002). The rights of strangers: theories of international hospitality, the global community, and political justice since Vitoria. Ashgate.

Chadwick, R., \& O'Connor, A. (2015). Ethical Theory and Global Challenges. In D. Moellendorf \& H. Widdows (Eds.). The Routledge Handbook of Global Ethics (pp. 23-33). Routledge.

Chen, A. K., \& Cummings, S. (2014). Public interest lawyering: a contemporary perspective. Wolters Kluwer Law \& Business.

Cohen, S. (2004). The nature of moral reasoning: the framework and activities of ethical deliberation, argument, and decision-making. Oxford University Press.

Curran, L. (2007). University law clinics and their value in undertaking client-centred law reform to provide a voice for clients' experiences. International Journal of Clinical Legal Education, 12, 105-130. 
Daniel, M. (2003). Legal ethics from the lawyer's point of view. Yale Journal of Law \& the Humanities, 15(2), 209-294.

Darwall, S. L. (2006). The second-person standpoint: morality, respect, and accountability. Harvard University Press.

Derrida, J. (2001). On cosmopolitanism and forgiveness. Routledge.

Douglas, S. (2015). Incorporating Emotional Intelligence in Legal Education: A Theoretical Perspective. e-Journal of Business Education $\mathcal{E}$ Scholarship of Teaching, 9(2), 56-71. http://ejbest.org/upload/e-JBEST Douglas - 9(2) 2015.pdf

Eberle, E. J. (1989). Toward Moral Responsibility in Lawyering: Further Thoughts on the Deontological Model of Legal Ethics. St John's Law Review, 64(1), 1-40.

Eigen, Z. J., \& Listokin, Y. (2012). Do lawyers really believe their own hype, and should they? a natural experiment. Journal of Legal Studies, 41(2), 239-267.

European Commission. (2020a). Climate change consequences. https://ec.europa.eu/clima/change/consequences en

European Commission. (2020b). Forced displacement: refugees, asylum-seekers and internally displaced people (IDPs). https://ec.europa.eu/echo/what-we-do/humanitarian$\underline{\text { aid/refugees-and-internally-displaced-persons en }}$

Fenske, H. (1980). International migration: Germany in the eighteenth century. Central European History, 13(4), 332-347. 
Fried, C. (1976). The lawyer as friend: The moral foundations of the lawyer-client relation. Yale Law Journal, 85(8), 1060-1090.

Giddings, J. M. (2013). Promoting justice through clinical legal education. Justice Press.

Goodwin-Gill, G. S., \& McAdam, J. (2007). The refugee in international law (3rd ed.). Oxford University Press.

Goodwin-Gill, G. S., \& McAdam, J. (2007). The refugee in international law (3rd ed.). Oxford University Press.

Hans, F. (1980). International Migration: Germany in the Eighteenth Century. Central European History, 13(4), 332-347.

Herring, J. (2017). Legal ethics (Second). Oxford University Press.

Hildebrand, C. (2017). Educating for British values: Kant's philosophical roadmap for cosmopolitan character education. Policy Futures in Education, 15(1), 20-37.

Hursthouse, R. (2013). Normative virtue ethics. In R. Shafer-Landau (Ed.), Ethical theory: an anthology (2nd ed., Ser. Blackwell philosophy anthologies, 34) (pp. 645-653). Wiley-Blackwell.

Immigration Law Practitioners' Association. (2018). ILPA's statement on the new immigration and asylum legal aid fixed fee (18 May 2020). https://ilpa.org.uk/ilpastatement-re-new-legal-aid-immigration-and-asylum-fixed-fee/ 
Johnson, R., \& Cureton, A. (2019). Kant's Moral Philosophy. In E. N. Zalta (Ed.), The

Stanford Encyclopedia of Philosophy.

\section{https:/plato.stanford.edu/archives/spr2019/entries/kant-moral/}

Jordà Òscar, Schularick, M., \& Taylor, A. M. (2010). Financial crises, credit booms, and external imbalances: 140 years of lessons (Ser. Nber working paper series, no. w16567). National Bureau of Economic Research. http://www.nber.org/papers/w16567.

Kant, I. (1948). The Moral Law: Kant's Groundwork of the Metaphysics of Morals. (H. J. Paton, Trans.). Hutchinson.

Kant, I. (1996). The Metaphysics of Morals (M. J., Gregor, Ed.). Cambridge University Press.

Kant, I. (2006). Toward perpetual peace and other writings on politics, peace, and history. (P. Kleingeld, Ed.). Yale University Press.

Kant, I. (2015). Critique of Practical Reason. (A. Reath \& M. J. Gregor, Eds.). Cambridge University Press.

Kirkup, J., \& Winnett, R. (2012, May 25). Theresa May interview: ‘We're going to give illegal migrants a really hostile reception'. The Daily Telegraph, 25. https://www.telegraph.co.uk/news/0/theresa-may-interview-going-give-illegal$\underline{\text { migrants-really-hostile/ }}$

Kleingeld, P. (1998). Kant's cosmopolitan law: world citizenship for a global order. Kantian Review, 2, 72-90. 
Kleingeld, P. (1999). Six varieties of cosmopolitanism in late eighteenth-century Germany. Journal of the History of Ideas, 60(3), 505-524.

Kleingeld, P. (2012). Kant and cosmopolitanism: the philosophical ideal of world citizenship. Cambridge University Press.

Knyght, R., Kakabadse, N., Kakabadse, A., \& Kouzmin A. (2011). When Rules and Principles are Not Enough: Insiders' Views and Narratives on the Global Financial Crisis. Journal of Change Management, 11(1), 45-67.

Korsgaard, C. M. (1996). Creating the Kingdom of Ends. Cambridge University Press.

Law Works. (2018). Submission to the Post-Implementation Review of the Legal Aid, Sentencing and Punishment of Offenders Act 2012. https://www.lawworks.org.uk/sites/default/files/files/LASPO\%20Review\%20submis sion $2 \% 20 \% 285 \% 29 \% 20 \% 281 \% 29$.pdf

Litonjua, M. D. (2008). The socio-political construction of globalization. International Review of Modern Sociology, 34(2), 253-278.

Lyon, A. D. (2012). Race bias and the importance of consciousness for criminal defense attorneys. Seattle University Law Review, 35(3), 755-768.

Mader, M., \& Schoen, H. (2019). The European refugee crisis, party competition, and voters' responses in Germany. West European Politics, 42(1), 67-90.

Madhloom, O. (2019). A normative approach to developing reflective legal practitioners: Kant and clinical legal education. The Law Teacher, 53(4), 416-430. 
McAllister, L. (1997). An adult learning framework for clinical education. In L. McAllister, M. Lincoln, \& D. Maloney (Eds.), Facilitating learning in clinical settings (pp. 1-26). Nelson Thornes Ltd.

Mitchell, J. B. (1980). The ethics of the criminal defense attorney: new answers to old questions. Stanford Law Review, 32(2), 293-337.

Motohide, S. (2016). On an East Asian Community, or Kant's Cosmopolitan Right Reconsidered. In N.-K. Kim (Ed.) Globalization and regional integration in Europe and Asia (pp. 123-139). Routledge.

Nascimento, A. (2014). Human Rights and the Paradigms of Cosmopolitanism: From Rights to Humanity. In M. Lutz-Bachmann \& A. Nascimento (Eds.), Human rights, human dignity, and cosmopolitan ideals: essays on critical theory and human rights (pp. 95117). Ashgate.

Nelson, W. (2008). Kant's formula of humanity. Mind, 117(465), 85-106.

Nicolson, D. (2016). 'Our roots began in (South) Africa': modelling law clinics to maximise social justice ends. International Journal of Clinical Legal Education, 23(3), 8888.

Nicolson, D. (2017). Teaching and learning legal ethics: what, how and why? In R. Grimes (Ed.), Re-thinking legal education under the civil and common law: a road map for constructive change (First, Ser. Legal pedagogy) (pp. 87-113). Taylor and Francis. 
Nussbaum, M. (2010). Patriotism and cosmopolitanism. In G. W. Brown \& D. Held (Eds.), The Cosmopolitanism Reader (pp. 151-162). Polity.

Papastephanou, M. (Ed.). (2016). Cosmopolitanism: educational, philosophical and historical perspectives. Springer

Payne, S. (1999). 'Dangerous and different': Reconstructions of madness in the 1990s and the role of mental health policy. In S. Watson \& L. Doyal (Eds.), Engendering social policy (pp. 180-195). Open University Press.

Pepper, S. L. (1986). The lawyer's amoral ethical role: defense, problem, and some possibilities. American Bar Foundation Research Journal, 1986(4), 613-636.

Pierik, R. H. M., \& Werner, W. G. (2010). Cosmopolitanism in context: perspectives from international law and political theory (Ser. Cambridge books online). Cambridge University Press.

Pogge, T. W. (1992). Cosmopolitanism and sovereignty. Ethics, 103(1), 48-75.

Rand, J. W. (2003). Understanding why good lawyers go bad: Using case studies in teaching cognitive bias in legal decision-making. Clinical Law Review, 9(2), 731-782.

Reiss, H., Nisbet, H. B., \& Reiss, H. (1991). Kant political writing (2nd ed.). Cambridge University Press. 
Webb, J. (2011). Taking values seriously: the democratic intellect and the place of values in the law school curriculum. In M. Robertson, L. Corbin, K. Tranter \& F. Bartlett (Eds.). The ethics project in legal education (9-32). Routledge.

Ruger, J. P. (2018). Global health justice and governance. Oxford University Press.

Sandel, M. J. (1996). Democracy's discontent: America in search of a public philosophy. Belknap Press of Harvard University Press.

Sarat, A., \& Scheingold, S. A. (1998). Cause Lawyering and the Reproduction of Professional Authority. In A. Sarat \& S. A. Scheingold (Eds.), Cause lawyering: political commitments and professional responsibilities (3-28). Oxford University Press.

Schwieler, E., \& Ekecrantz, S. (2011). Normative values in teachers' conceptions of teaching and learning in higher education: a belief system approach. International Journal for Academic Development, 16(1), 59-70.

Seleme, H. (2013). Defending the Guilty: A moral Justification. Ethical Perspectives, 20, 299-327.

Solicitors Regulation Authority (2018), Balancing duties in litigation. https://www.sra.org.uk/globalassets/documents/solicitors/freedom-inpractice/balancing-duties-in-litigation.pdf?version=49922b Solicitors Regulation Authority. (2020). SRA Principles. https://www.sra.org.uk/solicitors/standards-regulations/principles/ 
Stark, J. H. \& Milyavsky, M. (2019). Towards a better understanding of lawyers' judgmental biases in client representation: the role of need for cognitive closure. Washington University Journal of Law E Policy, 59(1), 173-216.

The Convention Relating to the Status of Refugees 1951.

The Office of the Immigration Services Commissioner. (2018). Position Statement. https://www.gov.uk/government/publications/oiscs-position-statement/oiscsposition-statement

Timmermann, J. (2007). Kant's groundwork of the metaphysics of morals: a commentary. Cambridge University Press.

United Kingdom. Parliament. (2014). Factsheet: Tackling illegal immigration in privately rented accommodation (clauses 22-28). https://assets.publishing.service.gov.uk/government/uploads/system/uploads/attach ment data/file/341876/Factsheet Landlords Aug 14.pdf

United Nations. (2020). Refugees. https://www.un.org/en/sections/issuesdepth/refugees/

Uthayakumar-Cumarasamy, A. (2020). The 'hostile environment' and the weaponization of the UK health system. Medicine, Conflict and Survival, 36(2), 132-136. Van Hooft, S. (2014). Cosmopolitanism: a philosophy for global ethics. Taylor and Francis. Wald, E., \& Pearce, R. G. (2016). Being good lawyers: relational approach to law practice. Georgetown Journal of Legal Ethics, 29(3), 601-648. 
Reviewed Article

Waldron, J. (2000). What is cosmopolitan? Journal of Political Philosophy, 8(2), 227-243.

Webber, F. (2019). On the creation of the UK's 'hostile environment'. Race $\mathcal{E}$ Class, 60(4), 76-87. 